\title{
Resuspension and particle transport in the Benthic Nepheloid Layer in and near Fram Strait in relation to faunal abundances and ${ }^{234} \mathrm{Th}$ depletion
}

\author{
M.M. Rutgers van der Loeff, R. Meyer, B. Rudels ${ }^{1}$ and E. Rachor \\ Alfred-Wegener-Institute for Polar- und Marine Research, Bremerhaven, Germany \\ mloeff@awi-bremerhaven.de \\ ${ }^{1}$ Finish Institute for Marine Research, Helsinki \\ Bert.Rudels@fimr.fi
}

\begin{abstract}
The West Spitsbergen Current, flowing northward through Fram Strait, causes a benthic nepheloid layer (BNL) on the western slope of the Yermak Plateau. This BNL is weaker on the eastern side of the Plateau and absent on the Greenland side of the Fram Strait where the East Greenland Current flows south. In this BNL we find throughout a depletion of ${ }^{234} \mathrm{Th}$ relative to its parent ${ }^{238} \mathrm{U}$, and we use this to study the particle dynamics in the BNL. The export flux from the ice-covered surface ocean and from a young bloom found in the ice-free waters off NE Greenland is shown to be negligible, allowing us to explain the ${ }^{234} \mathrm{Th}$ depletion by interaction with the sediment alone. The depletion, balanced by a similar excess in the surface layer of the sediment, implies the existence of a settlingresuspension loop with an average particle residence time of 1-2 months.

The asymmetry with a stronger resuspension loop on the western (80-120 $\left.\mathrm{mg} \mathrm{m}^{-2} \mathrm{~d}^{-1}\right)$ than on the eastern side of the Yermak Plateau $\left(1-15 \mathrm{mg} \mathrm{m}^{-2} \mathrm{~d}^{-1}\right)$ is reflected in the numbers of species and individuals of suspension feeders in box core samples, and in epifauna abundance as has been estimated from video observations. The suspension feeders thus contribute to deposit the particles that are advected from more productive ice-free regions. This explanation is in agreement with the eastwest asymmetry in the input of organic material to the sediments of the Yermak Plateau, which has been concluded by Soltwedel et al. (2000) from the distribution of pigments, bacterial activity and meiofauna abundances, observed in a concurrent study at the same stations.

On the West Spitsbergen shelf, a very intensive BNL was monitored over one month with a moored filtration system. A part of the sustained high suspended load may be advected over long distances. This study gives an example how the tracer ${ }^{234} \mathrm{Th}$ can help to determine to what extent suspended particles are in continuous exchange with the seafloor, and where biological mediation and chemical modification can be expected.
\end{abstract}

Keywords: RESUSPENSION, NEPHELOID LAYER, ZOOBENTHOS, THORIUM ISOTOPES, scavenging, sediment-water exchange

Regional index terms: Fram Strait, Arctic, Norwegian Sea, Northern North Atlantic, Spitsbergen

submitted to Deep-Sea Research I, 26.Sept.2001 


\section{INTRODUCTION}

The bottom water of the ocean has usually a higher load of suspended particulate material (SPM) than the clear water at intermediate depths (Biscaye and Eittreim, 1977). Such a Benthic Nepheloid Layer (BNL), may extend several hundred meters above the seafloor. It is maintained on one hand by fine particles like clay minerals that may have been transported over very long distances and that are kept in suspension because of the enhanced turbulence and shear near the seafloor; on the other hand it is maintained by resuspension (McCave, 1986). The highly dynamic local resuspension loop (Graf, 1997) includes settling of fresh particles through the water column (Billet et al., 1983), resuspension (Lampitt, 1985; modeled by Boudreau, 1997), aggregation and disaggregation (McCave, 1983, Hill and McCave, 2001). Benthic fauna plays a large role in this resuspension loop (Thomson et al., 1995, Graf and Rosenberg, 1997) and bacterial activities are enhanced by resuspension events (Wainright, 1987; Ritzrau and Graf, 1992). An important part of early diagenetic reactions, the transformations between the settling of particles and their ultimate burial, may in fact take place in this resuspension loop (Rutgers van der Loeff and Boudreau, 1997).

Suspended particles in a well-developed BNL, even at large water depths, are therefore a high-quality food source. Many organisms are adapted to feed on this, some (crinoids, sea feathers) obtain apparently advantage from their structures to feed at some height above the sea floor. The uptake of particles by a suspension feeding benthic community has been measured in an in-situ flume experiment on the Barents slope by Thomson et al. (1995).

These two very different aspects of the BNL: the long range advection of fine terrigenous particles on one hand, and the dynamic and biology-mediated cycling of fresh material in exchange with the sediment on the other, can in principle be distinguished using the tracer ${ }^{234} \mathrm{Th}$ (Bacon and Rutgers van der Loeff, 1989).

${ }^{234} \mathrm{Th}$ is a natural tracer that is well suited to study transport of particles in the ocean on a time scale of months. It is produced by ${ }^{238} \mathrm{U}$, which is an accurately known composite of sea salt, and decays with a half-life of 24.1 days. In the absence of removal processes, total (dissolved + particulate) ${ }^{234} \mathrm{Th}$ is in secular equilibrium with ${ }^{238} \mathrm{U}$ (i.e. ${ }^{234} \mathrm{Th} /{ }^{238} \mathrm{U}=1$ ), a situation found in most of the deep water column of the ocean. But ${ }^{234} \mathrm{Th}$ is removed by scavenging, which explains why coastal waters are depleted in the isotope (Kershaw and Young, 1988; Kersten et al., 1998). The isotope is also removed from the surface waters of the ocean by particles sinking our of the surface layer, which process is the basis for the use of this tracer for the quantification of export production (Tsunogai and Minagawa, 1976; Coale and Bruland, 1985; Eppley, 1989). In the internal ocean, from a depth of approx. $200 \mathrm{~m},{ }^{234} \mathrm{Th}$ reaches equilibrium with ${ }^{238} \mathrm{U}$, but sometimes it is found that ${ }^{234} \mathrm{Th}$ is depleted in the bottom water, which then is an indication of particle exchange between the bottom water and the surface sediment and can serve to quantify this exchange rate (Bacon and Rutgers van der Loeff, 1989, DeMaster et al., 1991, Rutgers van der Loeff and Boudreau, 1997, Turnevich and Springer, 2001).

The clearest signals of ${ }^{234} \mathrm{Th}$ depletion in deep-sea environments have been found in the high-energy regime of western boundary currents (Bacon and Rutgers van der Loeff, 1989; DeMaster et al., 1991), but, remarkably, we did not observe a depletion in three transects across the Antarctic Circumpolar Current (ACC) (Rutgers van der Loeff et al., submitted) where transmissometry (Biscaye and Eittreim, 1977) and particulate ${ }^{234} \mathrm{Th}$ did show the existence of an intensive BNL. Apparently, the bottom currents in the ACC are not strong enough for a sufficiently rapid resuspension cycle of local sediment. The role of bottom fauna in the resuspension loop has not been investigated in these studies.

Here we use ${ }^{234} \mathrm{Th}$ to describe the particle dynamics in an environment where benthic activity is known to play an important role in the settling-resuspension cycle. During the same expedition Soltwedel et al. (2000) observed high benthic activity and biomass on the west flank of the Yermak Plateau, which is exposed to the West Spitsbergen Current. We map the distribution of ${ }^{234} \mathrm{Th}$ in the 
nepheloid layer on a section between Spitsbergen and Greenland crossing the Yermak Plateau near Fram Strait. Other terms in the ${ }^{234} \mathrm{Th}$ budget are derived from measurements of the ${ }^{234} \mathrm{Th}$ depletion in surface waters and of its excess inventory in the sediment. We then present a budget of ${ }^{234} \mathrm{Th}$ in the nepheloid layer to derive the spatial distribution of exchange rates of suspended particles with surface sediments in the BNL, and discuss the results in relation to the export flux from the surface water, the current regime, and the distribution of bottom fauna.

\section{Hydrography}

Fig. 1

The hydrography of the study area during summer 1997 has been described by Rudels et al., 2000. Fram Strait (Figure 1) is the only deep passage between the Arctic Ocean and the Nordic Seas. The southward East Greenland Current is predominantly baroclinic with the strongest flow in the surface layer. The northward flow, the West Spitsbergen Current, appears to be steered by the bathymetry and is split in an eastern and western part by the Yermak Plateau. Enhanced vertical mixing over the Plateau, mainly by tidal mixing (Padman et al., 1992) causes here a reduction of the temperature maximum in the Atlantic core . On the eastern flank, the temperature of the Atlantic core increases from south to north, suggesting that some of the eastern inflow branch leaves the continental slope, enters the Sofia Deep, and reaches the far NE end of the Yermak Plateau.

Fig. 2

Fig. 3

The deeper layers of the West Spitsbergen Current have to follow the western flank of the Yermak Plateau. The deep part consists mainly of cold, low-salinity Norwegian Sea Deep Water (NSDW) (Figure 2), well distinct in its $\Theta-S$ characteristics from the outflowing Arctic deep waters of the European (EBDW) and Canada Basin (CBDW) (Figure 3). Close to the plateau NSDW is located high on the NW slope indicating a bottom-intensified flow (called the Yermak Slope Current by Schlichtholz and Houssais, 1999), which is absent on the SE slope.

\section{METHODS}

Sampling - Water samples were taken on the ARK XIII/2 expedition of RV "Polarstern" from 26.6.11.8.98 (Stein and Fahl, 1997) on a transect (B in Figure 1) between the northern Svalbard continental margin and the East Greenland continental margin across the Yermak Plateau. A second transect (D) across the Plateau was situated somewhat further north, whereas a third transect (E) crossed the eastern branch of the West Spitsbergen Current up to the Spitsbergen shelf. Seawater samples were collected with the CTD/Rosette from different water depths with enhanced depth resolution in the BNL at altitudes of 0-200 $\mathrm{m}$ above the seafloor. Surface water was collected from the ship's seawater supply.

Transmissometry - The distribution of the BNL was measured by monitoring the light transmission with a Chelsea transmissometer mounted on the Rosette and connected to the CTD. The system worked very reliably and the data have been used throughout as a selection criterion for water sampling. According to Gardner et al. (1993) there is a good relationship between beam attenuation and suspended load. The constant in the relationship depends on the type of particles. We therefore checked the algorithm by weighing filters obtained from the same water mass, and found that the results agreed to within $15 \%$. We thus used Gardner's algorithm for the NE Atlantic to convert the data to suspended load. In the open ocean, the calibration according to the Gardner 
algorithm can make use of the transmission in the clear water minimum as the transmission of virtually particle-free water. In the Barents Sea, the maximum transmission between the plankton-dominated upper water layer and the BNL did not reach these values of clear openocean water of intermediate depths. Consequently, the conversion of transmission values to suspended load had to be based here on transmission measurements in air and on the observations later on in the open ocean. This procedure did not cause uncertainty in the calibration, as the air and clear-water transmission readings of the instrument were very stable.

${ }^{234} \mathrm{Th}$ - was analysed according to Rutgers van der Loeff and Moore (1999). Briefly, 15-20L samples were collected with the Rosette, weighed and filtered by air pressure over a 1- $\mu \mathrm{m}$ polycarbonate filter. In the filtrate, Th was precipitated quantitatively with $\mathrm{MnO}_{2}$ which was subsequently filtered as well. The two filters with the particulate and dissolved fractions, respectively, were counted on board with a beta counter. Calibration was performed with spiked filters and checked with samples from intermediate depth assumed to be in secular equilibrium with ${ }^{238} \mathrm{U}$.

${ }^{234}$ Th in the sediment - was quantified using the same technique. Subsamples of thin slices of surface sediment were resuspended in distilled water and filtered over the same filter type and counted. These counts were corrected for self adsorption and background count rate from other beta emitters after Rutgers van der Loeff and Moore (1999). We estimate that the precision of the low inventories determined with this procedure is not better than approx. $25 \%$.

Mooring - The time-development of particle fluxes in the water column and in the BNL was studied by the deployment of a filtration- and adsorption device. This so-called multisampler (COSS-built) performs a time-programmed filtration of several hundred liters over $142 \mathrm{~mm}$ diameter $1 \mu \mathrm{m}$ polycarbonate filters. The filtrate then passes over $\mathrm{MnO}_{2}$-coated absorbers to collect the dissolved ${ }^{234} \mathrm{Th}$ phase. Originally, the deployment was planned for a depth of $2000 \mathrm{~m}$, but ice conditions forced us to a shallower location on the shelf edge of Spitsbergen and the instrument was deployed at $80^{\circ} 10.47^{\prime} \mathrm{N} / 10^{\circ} 24.48^{\prime} \mathrm{E}$ in a water depth of $523 \mathrm{~m}$. The multisampler was mounted at $40 \mathrm{~m}$ above ground and was programmed to sample the bottom water every 3 days for 4 hours. We gave priority to long pumping times, accepting the risk of power failure in the last phase of the deployment. The instrument worked properly over 6 cycles, but the precision of the measurement of filtered volume turned out to be only approx. $10 \%$, insufficient for the determination of depletion of total ${ }^{234} \mathrm{Th}$ with respect to ${ }^{238} \mathrm{U}$. The precision of SPM and particulate ${ }^{234} \mathrm{Th}$ concentrations is determined by this volume measurement.

Macrofauna - samples were taken as sub-samples (cores of $228 \mathrm{~cm}^{2}$ surface area) out of large geological box corers $\left(0,25 \mathrm{~m}^{2}\right)$ and sieved over meshes of $0,25 \mathrm{~mm}$. At stations $58,64,65,68$, two sub-samples were obtained from different large box corers (mean values); in the other locations, only one sub-sample was available.

\section{RESULTS}

\section{Sections B and D}

Fig. 4

SPM at shallow depth - Even in low-productivity waters under heavy ice cover plankton is responsible for the enhanced suspended loads in surface waters (only schematically indicated in Figure 4). On the shelf, suspended load is enhanced over the entire water column as a result of coastal inputs of terrigenous matter, sediment resuspension, and plankton growth. 
SPM near-bottom - A well-developed BNL is present in the eastern range of Fram Strait. The most intense nepheloid layers are observed on the western slope of the Yermak Plateau and especially in the coastal branch (Profile E). There is a remarkable asymmetry at the Yermak plateau with higher suspended load on the western side than on the eastern side, observed on both transects B and D. The BNL collapses to a complete absence on the Greenland side of the Strait and on the steep Greenland slope.

These observations are explained in the following way: On the Greenland side, clear deep Arctic water is flowing south. The coarse sediments are indication of high current speeds, but there is not sufficient fine material available to be resuspended. On the Yermak plateau there is sufficient turbulence, created both by tides, which are strongly enhanced over the slopes of the Plateau (Padman et al., 1992), and by residual currents, to maintain a well-mixed near-bottom layer where material is resuspended or kept in suspension. We explain the high loads on the west flank as related to the West Spitsbergen Current/Yermak Slope Current, forced to the right by the Coriolis acceleration (Figure 2).

Fig. 5

${ }^{234} \mathrm{Th}$ - A near-bottom depletion of total (dissolved + particulate) ${ }^{234} \mathrm{Th}$ could be observed (Figure 5) that closely follows the distribution of SPM (

Figure 4). The strongest depletion is associated with the WSC/YSC on the west flank of the Yermak Plateau and with the intensive BNL in the coastal branch (section E). Such depletions of ${ }^{234} \mathrm{Th}$ imply that the nepheloid layer cannot be explained exclusively by long-range transport, but must be maintained by a constant exchange with the seafloor on a time scale of weeks. Depletion is absent over the Greenland slope.

\section{The Spitsbergen shelf: sections E}

Fig. 6

The unusually intensive BNL on the Spitsbergen shelf was monitored with the moored filtration device (Figure 6). This high suspended load observed with the CTD (station 61) was reproduced by this instrument in the following 16 days (Figure 7), to become more variable in the later period up to recovery.

Fig. 7

\section{Export from the surface water}

Before we can proceed with the calculation of the timescale of this exchange from a ${ }^{234} \mathrm{Th}$ budget in the Benthic Nepheloid Layer, we must make an estimate of the input of ${ }^{234} \mathrm{Th}$ from above by settling particles.

Fig. 8

The ${ }^{234} \mathrm{Th}$ scavenging technique, used here primarily for studying particle dynamics in the BNL, has been developed originally to study the export of particles from the euphotic zone. The distribution of ${ }^{234} \mathrm{Th}$ in surface waters on sections C,D and E (Figure 8) gives a very clear picture of the development of plankton blooms during the expedition:

- Although ice algae were observed throughout, the water layer just beneath the thick ice cover (stations 77-91) showed no sign of a developing bloom. The depletion of total ${ }^{234} \mathrm{Th}$ remained within $5 \%$ of ${ }^{238} \mathrm{U}$, which is in steady state equivalent to an export flux of only $67 \mathrm{dpm} \mathrm{m}^{-2} \mathrm{~d}^{-1}$ from the upper $20 \mathrm{~m}$. This corresponds with two short deployments of cylindrical sediment traps (Bauerfeind and Shevchenko in Stein and Fahl, 1998) on ice floes at $82^{\circ} 21^{\prime} \mathrm{N}, 4^{\circ} 12^{\prime} \mathrm{E}$ and at $81^{\circ} 50^{\prime} \mathrm{N}, 6^{\circ} 53^{\prime} \mathrm{E}$ (Bauerfeind, pers. comm.), where we measured a flux of $80-100 \mathrm{dpm} \mathrm{m}^{-2} \mathrm{~d}^{-1}$ at $40 \mathrm{~m}$ depth. 
- A plankton bloom observed in the unexpectedly ice-free water mass off NE Greenland is clearly reflected in an increase in particulate ${ }^{234} \mathrm{Th}$, but a significant export production has occurred only at station $72 \mathrm{a}$. At stations 73 and $74,{ }^{234} \mathrm{Th}$ is still close to equilibrium with its parent.

- On the Spitsbergen shelf, total ${ }^{234}$ Th was depleted in the surface water by $29 \%$ during deployment on July 7 (station 61), implying that a massive bloom had sunk out in the weeks before. During recovery on August 3 (station 99, Figure 6), a similar depletion was measured (22\% at $10 \mathrm{~m}, 28 \%$ at $20 \mathrm{~m}$ depth).

\section{DISCUSSION}

\section{${ }^{234}$ Th fluxes from surface to deep waters.}

The ${ }^{234} \mathrm{Th}$ data from the surface water show that particle export was significant only in ice-free water over the Spitsbergen shelf. The highest depletion in the surface water on transect D (26\%, Figure 8) was observed at station 94 near the ice edge, implying that the classical bloom at the marginal ice zone had already resulted in a large particle export. Over the Yermak Plateau, the thick ice-cover prevented a bloom to occur. In the East Greenland Current, the retreat of the ice cover had caused a bloom to develop, but apart from one station (72a) the export flux had not yet set in. This delay is usually found in studies of natural (Rutgers van der Loeff et al., 1997) or induced blooms (Charette and Buesseler, 2000; Smetacek et al., 2001). This general distribution agrees with the transition of sedimentation regimes characterized by ice-covered polar water masses on the Greenland side to icefree Atlantic water masses in the east (Hebbeln and Wefer, 1991) and with determinations of sediment oxygen uptake on the western (Sauter et al., 2001) and eastern (Hulth et al., 1994) side of Fram Strait. Our transect was too far north to be influenced by the special situation of the Northeast Water Polynia with clearly enhanced organic flux rates (Rowe, 1997) and correspondingly high scavenging rates of ${ }^{234}$ Th (Cochran et al., 1995).

We conclude that, apart from the Barents shelf and the ice-free region on the Spitsbergen shelf, the rain rate of organic particles and of ${ }^{234} \mathrm{Th}$ from the surface ocean to the deep sea was very low.

\section{${ }^{234}$ Th Balance near the seafloor}

The depletion of ${ }^{234} \mathrm{Th}$ in the water column must be balanced by an excess in the sediment, although not necessarily at the same station. Nevertheless, an approximate balance is met at all stations, with high inventories on the Barents and Spitsbergen shelves, intermediate ones on the Yermak Plateau, and very low inventories on the Greenland slope (Figure 9). Our results for the Barents Shelf (station 57, we have no data shallower than $200 \mathrm{~m}$ ) are in line with the study of Coppola et al. (submitted) who also found ${ }^{234} \mathrm{Th}$ depletion over the entire water column.

Fig. 9

The exchange between the seafloor and the BNL is only part of this full ${ }^{234} \mathrm{Th}$ budget. If we wish to estimate the residence time $\tau$ of resuspended particles in the BNL from the ${ }^{234} \mathrm{Th}$ depletion in the BNL, all components of the budget, including the vertical rain rate, have to be taken into account. After the model of Rutgers van der Loeff and Boudreau, (1997), which describes the distribution of ${ }^{234} \mathrm{Th}$ in the resuspension-settling cycle of a single class of particles in a well-mixed nepheloid layer, $\tau$ is given by (for a full list of parameters and their units see Table 2):

eq. 1 $\tau=\frac{I_{P}}{D+R+S}$, where

$\mathrm{I}_{\mathrm{P}}$ inventory of particulate ${ }^{234} \mathrm{Th}$ in the $\mathrm{BNL}, \mathrm{I}_{\mathrm{P}}=\mathrm{hC}_{\mathrm{pBNL}}$

$\mathrm{D}$ : $\quad$ Ingrowth from depletion in the $\mathrm{BNL}, \mathrm{D}=\mathrm{h}\left(\mathrm{P}_{\mathrm{d}}-\mathrm{C}_{\mathrm{tBNL}} \lambda\right)$

R: $\quad$ resuspension flux, $\mathrm{R}=\mathrm{KL} \varphi_{\mathrm{ss}} \mathrm{B}$ 。

S: $\quad$ settling flux of ${ }^{234} \mathrm{Th}, \mathrm{S}=-\mathrm{w}_{\mathrm{S}} \mathrm{C}_{\mathrm{pc}}$ 
where

h $\quad$ Height of bottom boundary layer (BNL)

$\mathrm{C}_{\mathrm{pBNL}}$ : $\quad$ particulate activity of ${ }^{234} \mathrm{Th}$ in BNL

$\mathrm{C}_{\mathrm{tBNL}}$ : total (dissolved+particulate) activity of ${ }^{234} \mathrm{Th}$ in $\mathrm{BNL}$

$\mathrm{P}_{\mathrm{d}} \quad$ production rate of ${ }^{234} \mathrm{Th}$ from ${ }^{238} \mathrm{U}$

$\lambda$ : $\quad$ decay constant of ${ }^{234} \mathrm{Th}$

$\mathrm{w}_{\mathrm{S}} \quad$ particle settling rate

$\mathrm{C}_{\mathrm{pc}} \quad$ particulate activity of ${ }^{234} \mathrm{Th}$ in clear water above the BNL

$\mathrm{K} \quad$ resuspension rate

L thickness of resuspension zone (surface sediment)

$\varphi_{\text {ss }} \quad$ particulate volume fraction in sediment

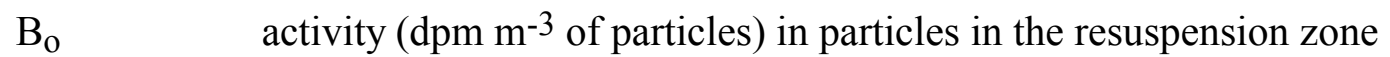

The second term in the denominator of eq. 1 takes into account that resuspended sediments have a non-zero ${ }^{234} \mathrm{Th}$ activity. We have measured this activity after collecting the upper fluffy layer of approx. $2.5 \mathrm{~mm}$ from the box cores with a syringe. As expected, we found here the highest activity in the sediment, but the activity on a weight basis was only $40-80 \mathrm{dpm} / \mathrm{g}$, or less than $1 \%$ of the average activity on SPM. This means that term 2 in eq. 1 can be neglected, giving

eq. 2

$$
\tau=\frac{\mathrm{I}_{\mathrm{p}}}{\mathrm{I}_{\mathrm{D}} \lambda+\mathrm{S}}
$$

where $I_{D}$ is the inventory in the BNL of the depletion of ${ }^{234} \mathrm{Th}\left(\mathrm{dpm} \mathrm{m}^{-2}\right)$. On the Greenland slope and on the Yermak Plateau, the low export flux plays a minor role in the ${ }^{234} \mathrm{Th}$ budget. If we realize that a large part of this low flux must remineralize in the water column (Suess, 1980) thereby also releasing ${ }^{234}$ Th (Usbeck et al., submitted), the contribution from vertical particle rain (term 3 in the denominator of eq. 1) to the ${ }^{234} \mathrm{Th}$ budget in the BNL can equally be neglected, giving

eq. $3 \quad \tau=\frac{I_{p}}{I_{D} \lambda}$

The average residence time of particles in the near-bottom water is on the order of 6 weeks (Table 1) and does not show a clear geographical trend. In the assumptions that are on the basis of eq. 1 (steady state and negligible net sediment accumulation), the particle recycling rate $\mathrm{F}$, which equals both the particle deposition rate and the resuspension rate, can now be derived from

eq. $4 \quad \mathrm{~F}=\mathrm{C}_{\mathrm{SPM}} / \tau$

where $\mathrm{C}_{\mathrm{SPM}}$ is the concentration of suspended particles in the BNL. The distribution of the recycling rate over transects B and D (Figure 10) shows the intensive exchange between BNL and sediment over the Yermak Plateau.

Fig. 10

The intensity of the benthic particle recycling can be compared with the accumulation rate of the sediment. The net sediment accumulation rate (SAR) on the western Yermak slope is remarkably high and variable. The Holocene SAR at station 65 (the station with the maximum recycling rate on section B, Figure 10), amounts to $9 \mathrm{~g} \mathrm{~cm}^{-2} \mathrm{kyr}^{-1}$, corresponding to $250 \mathrm{mg} \mathrm{m}^{-2} \mathrm{~d}^{-1}$ (core PS2837-5, Hass et al., 
2000), but nearby cores have accumulation rates that are an order of magnitude lower, and especially on the Plateau the SAR is very low. This implies that locally the sedimentation rate is much higher than the recycling loop observed with the ${ }^{234} \mathrm{Th}$ tracer. We should realize that we compare here very recent fluxes averaged over a time scale of a few months (a few half lives of ${ }^{234} \mathrm{Th}$ ) with long-time averages that may be controlled by seasonal processes like ice melt or rarer events. But the comparison suggests that an appreciable part of the sedimentation concerns long-range transport of particles in suspension that have reached a steady-state exchange with the ${ }^{234} \mathrm{Th}$ in the bottom water and do not contribute to additional scavenging as long as they are not involved in the resuspension loop (Bacon and Rutgers van der Loeff, 1989). This explanation would require that the inventory of ${ }^{234} \mathrm{Th}$ excess in the sediment be higher than the depletion in the overlying water column, but our methods are not sufficiently precise to detect such an imbalance (Figure 9; Table 1).

\section{Strong resuspension in the coastal branch of WSC}

On the Barents and Spitsbergen shelves, the ${ }^{234} \mathrm{Th}$ input from the water column cannot be neglected, and $\tau$ has to be calculated from eq. 2 . As the ${ }^{234} \mathrm{Th}$ settling flux $\mathrm{S}$ must, in steady state, be balanced by the depletion $\mathrm{I}_{\mathrm{Dsw}}$ in the overlying water column, we can write

eq. 5

$$
\tau=\frac{I_{p}}{\left(I_{D}+I_{D s w}\right) \lambda}
$$

For the Barents shelf, we have insufficient data to derive $\mathrm{I}_{\text {Dsw }}$, but for station 61/99 we have calculated $\tau$ with eq. 5. At this station, the corresponding particle recycling rate is $1100-1.900 \mathrm{mg} \mathrm{m}^{-2}$ $\mathrm{d}^{-1}$, (Table 1), an order of magnitude higher than the values found on the Yermak Plateau (Figure 10). Although the intensity of the BNL was three times higher than anywhere else observed on this expedition, the depletion of ${ }^{234} \mathrm{Th}$ was similar. This is explained in part by the export of ${ }^{234} \mathrm{Th}$ from the overlying water column, which tends to fill up the depletion in the BNL. It also suggests that a large part of the suspended load is not involved in a recent sedimentation-resuspension cycle, a situation related to the situation at station 65 discussed above. We hypothesize that the water is derived from the Barents shelf, and that the original depletion has had enough time (several half-lives) to grow towards equilibrium during its transport north. Indeed, intense nepheloid layers have been observed before along the shelf/slope around $75^{\circ} \mathrm{S}$ (Thomson et al., 1995). Thus, it is likely that our instrument monitored the transport of sediment-laden bottom waters produced during winter freezing on the Barents shelf. This process was studied closer to one of its origins, at Storfjord, by Schauer (1995).

\section{Suspension feeding bottom fauna:}

One of the aims of this study is to link the observations on particle dynamics with the observations on the distribution of bottom fauna and on its feeding mechanisms. In quantitative box core samples collected on the southern transect (B) we analysed the density and species composition of macrozoobenthos. Apart from the relatively rich shelf and upper slope samples, we found the highest numbers of species and of individuals on the Yermak Plateau and especially its western slope (Figure 11). The east-west asymmetry is even more pronounced for suspension feeders (Spongia + Bivalvia, indicated by black bars in Figure 11) and corresponds well with the distribution of the nepheloid layer.

Fig. 11

Video observations confirmed that the west flank of the Yermak Plateau, with its well-developed BNL, was more densely populated, with more burrowing organisms and abundant suspension feeders like crinoids, sea feathers and soft corals. The east flank epifauna was less dense with less specialized suspension feeders. (Soltwedel, Thiel and Sablotny, pers. comm.). 


\section{The role of bottom fauna in the benthic particle cycle}

Bottom fauna can be actively involved in capturing particles from the BNL and in their resuspension. In the present study, we have no indication for a role of the bottom fauna in the resuspension process and we assume that the boundary current along the Yermak Slope is strong enough to resuspend particles from the seafloor. But the widespread occurrence of filter-feeding organisms shows the importance of biota in the sedimentation around the Yermak Plateau. Where the BNL is well developed, the bottom fauna is specialized in suspension feeding. As the vertical rain rate is very low in the ice-covered regions of the Yermak Plateau, the advection of organic-rich particles in the BNL may constitute an important food source for the fauna. A supply of organic material from the south was also hypothesized by Soltwedel et al. (2000) to explain the relative richness of the western flank of the Yermak Plateau in terms of pigments, microbial biomass and activity, and of meiofauna abundance. Organic-rich particles originating from more productive Atlantic waters further south or from the Spitsbergen shelf may have accumulated near the seafloor and carried northward in the strong near-bottom currents.

If such organic-rich particles were transported in suspension over long distances without exchange with the seafloor, this food supply route would not be reflected in a depletion of ${ }^{234} \mathrm{Th}$ in the BNL. The observed ${ }^{234} \mathrm{Th}$ depletion shows that at least a fraction of the suspended load exchanges with the seafloor. The flux of organic carbon involved in the settling-resuspension loop can be roughly estimated from Figure 10. The $\mathrm{C}_{\text {org }}$ content of surface sediments is about 5-10 $\mathrm{mg} \mathrm{g}^{-1}$ (Sauter et al., 2001). As the $\mathrm{C}_{\text {org }}$ content in material suspended in the BNL is higher (Rutgers van der Loeff and Moore, 1997), we use a value of $40 \mathrm{mg} \mathrm{g}^{-1}$ and find a turnover rate of $1-5 \mathrm{mg} \mathrm{C} \mathrm{m}^{-2} \mathrm{~d}^{-1}$ on the Plateau and its western flank. We have not determined the carbon requirements of macrozoobenthos on the Yermak Plateau, but analyses on the Laptev Slope and Lomonosov Ridge suggest this to be on the order of $0.5-2 \mathrm{mg} \mathrm{C} \mathrm{m}^{-2} \mathrm{~d}^{-1}$ in the 1000-2000m depth range (Deubel, 2000). While realizing that this data is not from the same area, we conclude that macrobenthic activity is of the same order as the benthic particle loop as derived from the depletion of ${ }^{234} \mathrm{Th}$. Suspension feeding may thus contribute significantly to the removal of particles towards the sediment.

This study shows how the tracer ${ }^{234} \mathrm{Th}$ helps to describe aspects of the particle dynamics in the BNL that are difficult to obtain by other means. The data not only show that the rich fauna on the Yermak slope is maintained by a supply of suspended particles from a distant source, but also that these particles are involved in an intensive exchange with the seafloor, an exchange by which they may be chemically modified (Rutgers van der Loeff and Boudreau, 1997).

\section{Acknowledgments}

We thank captain and crew of RV Polarstern for their assistance. Axel Maibaum took care of the multisampler and its deployment, with assistance from Edi Bauerfeind and Ekkehard Schütt. We have appreciated the inspiration from the epifauna team of Hjalmar Thiel and the live benthic video sessions provided by Thomas Soltwedel and Burkhard Sablotny. We thank Christian Hass for helpful comments. This is AWI publication number $\mathrm{xxx}$. 


\section{References:}

Bacon, M.P. and Rutgers van der Loeff, M.M., 1989. Removal of Thorium-234 by scavenging in the bottom nepheloid layer of the ocean. Earth Planet. Sci. Lett., 92: 157-164.

Billet, D.S.M., Lampitt, R.S., Rice, A.L. and Mantoura, R.F.C., 1983. Seasonal sedimentation of phytoplankton to the deep-sea benthos. Nature, 302: 520-522.

Biscaye, P.E. and Eittreim, S.L., 1977. Suspended particulate loads and transport in the nepholoid layer of the abyssal Atlantic Ocean. Mar. Geol., 23: 155-172.

Boudreau, B.P., 1997. A mathematical model for coupled sediment-suspension interactions. J. Mar. Syst., 11: 279-302.

Charette, M.A. and Buesseler, K.O., 2000. Does iron fertilization lead to rapid carbon export in the Southern Ocean? Geochem. Geophys. Geosyst., 1(13.10): 2000 GC000069.

Coale, K.H. and Bruland, K.W., 1985. 234Th:238U disequilibria within the California current. Limnol. Oceanogr., 30(1): 22- 33.

Cochran, K., Barnes, C., Achman, D. and Hirschberg, D.J., 1995. Thorium-234/Uranium-238 disequilibrium as an indicator of scavenging rates and particulate organic carbon fluxes in the Northeast Water Polynya, Greenland. J. Geophys. Res., 100(C3): 499-4410.

Coppola, L., Roy-Barman, M., Wassmann, P. and Jeandel, C., submitted. Calibration of sediment traps and particulate organic carbon using ${ }^{234} \mathrm{Th}$ in the Barents Sea. Mar. Chem.

DeMaster, D.J., Brewster, D.C., McKee, B.A. and Nittrouer, C.A., 1991. Rates of particle scavenging, sediment reworking, and longitudinal ripple formation at the HEBBLE site based on measurements of 234Th and 210Pb. Mar. Geol., 99: 423-444.

Deubel, H., 2000. Structures and nutrition requirements of macrozoobenthic communities in the area of the Lomonossov Ridge in the Arcitc Ocean. Reports on Polar Research, 370: 147pp.

Eppley, R.W., 1989. New production: history, methods and problems. In: W.H. Berger, V. Smetacek and G. Wefer (Editors), Dahlem Workshop on "Productivity of the Ocean: Present and Past". Wiley, New York, pp. 85-97.

Gardner, W.D., Walsh, I.D. and Richardson, M.J., 1993. Biophysical forcing of particle production and distribution during a spring bloom in the North Atlantic. Deep-Sea Res. II, 40(1/2): 171195.

Graf, G., 1997. SCOR Working Group 95: sediment suspension and sea bed properties. J. Mar. Syst., 11: 267-268.

Graf, G. and Rosenberg, R., 1997. Bioresuspension and biodeposition: a review. J. Mar. Syst., 11: 269-278.

Hass, H.C., Spielhagen, R.F. and Nørgaard-Pedersen, 2000. Climate variability and deep-ocean flow at the Arctic/North Atlantic gateway. EOS, 81(48): F674.

Hebbeln, D. and Wefer, G., 1991. Effects of the ice coverage and ice-rafted material on sedimentation in Fram Strait. Nature, 350: 409-411.

Hill, P.S. and McCave, I.N., 2001. Suspended particle transport in benthic boundary layers. In: B.P. Boudreau and B.B. Jorgensen (Editors), The Benthic Boundary Layer. Transport processes and biogeochemistry. Oxford University Press, New York, pp. 78-103.

Kershaw, P. and Young, A., 1988. Scavenging of 234Th in the eastern Irish Sea. J. Environm. Radioact., 6: 1-23.

Kersten, M., Thomsen, S., Priebsch, W. and Garbe-Schönberg, C.-D., 1998. Scavenging and particle residence times determined from $234 \mathrm{Th} / 238 \mathrm{U}$ disequilibria in the coastal waters of Mecklenburg Bay. Appl. Geochem., 13: 339-347.

Lampitt, R.S., 1985. Evidence for the seasonal deposition of detritus to the deep-sea floor and its subsequent resuspension. Deep-Sea Res., 32: 885-897.

McCave, I.N., 1983. Particle size spectra, behavior and origin of nepheloid layers over the Nova Scotian Continental Rise. J. Geophys. Res., 83: 1971-1979.

McCave, I.N., 1986. Local and global aspects of the bottom nepheloid layers in the world ocean. Neth. J. Sea Res., 20(2/3): 167- 181.

Padman, P., Plueddemann, A.J., Muench, R.D. and Pinkel, R., 1992. Diurnal tides near the Yermak Plateau. J. Geophys. Res., 97: 12639-12652. 
Ritzrau, W. and Graf, G., 1992. Increase of microbial biomass in the benthic turbidity zone of Kiel Bight, Baltic Sea, after resuspension by a storm event. Limnol. Oceanogr., 37(5): 398-410.

Rowe, G.T. et al., 1997. Sediment community biomass and respiration in the Northeast Wter Polynya, Greenland: a numerical simulation of benthic lander and spade core data. J. Mar. Syst., 10: 497-515.

Rudels, B., Jones, E.P., Anderson, L.G. and Kattner, G., 1994. On the intermediate depth waters of the Arctic ocean. In: O.M. Johannessen, R.D. Muench and J.E. Overland (Editors), The Polar Oceans and their role in shaping the global environment: the Nansen centennial volume. Geophysical Monograph 85. American Geophysical Union, Washington DC, USA, pp. 33-46.

Rudels, B. et al., 2000. Water mass distribution in Fram Strait and over the Yermak Plateau in summer 1997. Ann. Geophysicae, 18: 687-705.

Rutgers van der Loeff, M.M. and Boudreau, B.P., 1997. The effect of resuspension on chemical exchanges at the sediment water interface - A modelling and natural radiotracer approach. J. Mar. Syst., 11: 305-342.

Rutgers van der Loeff, M.M., Friedrich, J. and Bathmann, U.V., 1997. Carbon export during the spring bloom at the southern Polar Front, determined with the natural tracer ${ }^{234} \mathrm{Th}$. Deep-Sea Res. II, 44(1/2): 457-478.

Rutgers van der Loeff, M.M. et al., submitted. Radionuclides as tracers for particle flux and transport of water masses in the Atlantic sector of the Southern Ocean. In: G. Wefer, V. Ratmeyer and G. Meinecke (Editors), SFB 261 Synthesis Volume. Springer.

Rutgers van der Loeff, M.M. and Moore, W.S., 1999. Determination of natural radioactive tracers. Chapter 13. In: K. Grasshoff, M. Ehrhardt and K. Kremling (Editors), Methods of Seawater Analysis. Verlag Chemie, Weinheim, pp. 365-397.

Sauter, E.J., Schlüter, M. and Suess, E., 2001. Organic carbon flux and remineralization in surface sediments from the northern North Atlantic derived from pore-water oxygen microprofiles. Deep-Sea Res. I, 48: 529-553.

Schauer, U., 1995. The release of brine-enriched shelf water from Storfjord into the Norwegian Sea. J. Geophys. Res., 100: 16015-16028.

Schlichtholz, P. and Houssais, M.-N., 1999. An inverse modeling study in Fram Strait. Part I: dynamics and circulation. Deep-Sea Res. II, 46: 1083-1135.

Smetacek, V., Bathmann, U. and El Naggar, S., 2001. The Expeditions ANTARKTIS XVIII/1-2 of the Research Vessel "Polarstern" in 2000. Reports on Polar and Marine Research, 400: 252pp.

Soltwedel, T., Mokievsky, V. and Schewe, I., 2000. Benthic activity and biomass on the Yermak Plateau and in adjacent deep-sea regions northwest of Svalbard. Deep-Sea Res. I, 47(9): 17611785.

Stein, R. and Fahl, K., 1997. Scientific Cruise Report of the Arctic Expedition ARK-XIII/2 of RV "Polarstern" in 1997. . Ber. Polarforsch., 255: 235 pp.

Suess, E., 1980. Particulate carbon flux in the oceans - relation to surface productivity and oxygen utilization. Nature, 288: 260-263.

Thomsen, L., Graf, G., Juterzenka, K.v. and Witte, U., 1995. An in situ experiment to investigate the depletion of seston above an interface feeder field on the continental slope of the western Barents Sea. Mar. Ecol. Progr. Ser., 123: 295-300.

Tsunogai, S. and Minagawa, M., 1976. Vertical flux of organic materials estimated from Th-234 in the ocean., Book of Abstracts, Joint Oceanographic Assembly, 13-24 Sept. 1976, Edinburgh, pp. 156.

Turnevich, R. and Springer, B.M., 2001. Do bottom mixed layers influence 234Th dynamics in the abyssal near-bottom water column? Deep-Sea Res. I, 48: 1279-1307.

Usbeck, R., Rutgers van der Loeff, M.M., Hoppema, M. and Schlitzer, R., submitted. Shallow mineralization in the Weddell Gyre. Geochemistry, Geophysics, Geosystems, submitted.

Wainright, S.C., 1987. Stimulation of heterotrophic microplankton production by resuspended marine sediments. Science, 238(18.12): 1710-1712. 


\section{Figure Legends}

Figure 1. Map of study area with station positions, location of transects, major current system formed by the East Greenland Current (EGC) and the West Spitsbergen Current (WSC), and the hypothesized ventilation of the Sofia Deep by the eastern branch of the WSC. The position of the Yermak Plateau is illustrated by the $1000 \mathrm{~m}$ depth contour

Figure 2. Salinity section from transect B.

Figure 3. $\Theta-S$ diagram from stations 60,66 and 70 on transect B (positions indicated in Figure 2) and station 87 on section D, showing the difference between northward flowing NSDW and southward flowing Arctic deep waters of the European (EBDW) and Canada Basin (CBDW).

Figure 4. Distribution of suspended particulate matter (in $\mu \mathrm{g} / \mathrm{L}$ ) on the three transects, derived from transmissometry after the algorithm of Gardner et al. (1993). Rosette casts in the BNL are represented by vertical bars, on which sampling depths have been indicated.

Figure 5. Depletion of ${ }^{234} \mathrm{Th}$ (in \% with respect to the parent ${ }^{238} \mathrm{U}$ ) in bottom water on the same sections as given in Figure 4. Stations and sampling depths indicated as in Figure 4.

Figure 6. Distribution of suspended material in the water column at the site where a particle sampler was deployed at the time of deployment (July 7, Station 61) and of recovery (Aug. 8, Station 99).

Figure 7. Suspended load (upper panel) and particulate ${ }^{234} \mathrm{Th}$ activity (lower panel) in the BNL at Station 61/99 as measured with the multisampler (filled diamonds) and with Rosette casts (open circles).

Figure 8. Particulate (open circles) and total (particulate + dissolved, closed circles) ${ }^{234} \mathrm{Th} /{ }^{238} \mathrm{U}$ activity ratio in surface waters in the polynia over the Greenland slope (stations 72a-74), along section C (station 77-79), D (stations 79-93), and across the ice edge at station 94 to the deployment station (99) on the Spitsbergen shelf.

Figure 9. ${ }^{234}$ Th depletion in the water column (upper panel) and ${ }^{234}$ Th excess in the sediment (middle panel) for four stations (74: PS2846-5; 64: PS2836-8; 99: PS2867-8; 57: PS2830-9) representing the different current and sedimentation regimes, with their locations indicated on a depth plot (lower panel). Numbers in the graphs are inventories in $\mathrm{dpm} \mathrm{cm}^{-2}$.

Figure 10. Particle recycling (deposition and resuspension) rate $\mathrm{F}$ on transects $\mathrm{B}$ (closed symbols, station 65 indicated) and D (open symbols) after eq. 3 and eq. 4.

Figure 11. Numbers of macrozoobenthos species (middle panel) and individuals (lower panel) with fraction made up by Spongia and Bivalvia (black) in quantitative box core samples compared with the distribution of suspended matter in transect B (upper panel, from

Figure 4). 
Table 1. Stations with position, water depth, the inventories in the lower $100 \mathrm{~m}$ of the water column of particulate ${ }^{234} \mathrm{Th}\left(\mathrm{C}_{\mathrm{p}}\right),{ }^{234} \mathrm{Th}$ depletion $\left({ }^{238} \mathrm{U}-\mathrm{C}_{\mathrm{t}}\right)$ and suspended material from transmissometry (SPM), the particle residence time in the BNL $(100 \mathrm{~m})$ after eq. 3 , and the excess ${ }^{234} \mathrm{Th}$ inventory in the sediment.

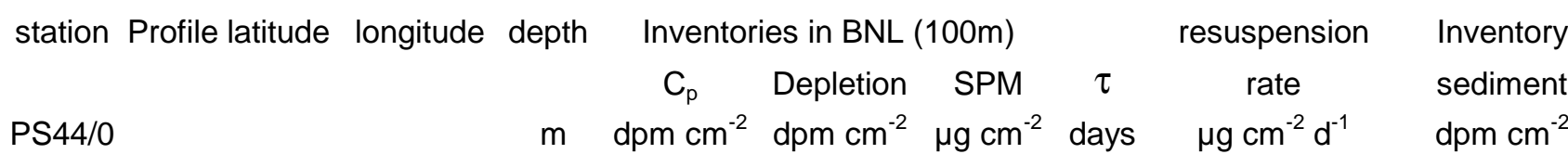

\begin{tabular}{|c|c|c|c|c|c|c|c|c|c|c|}
\hline 50 & A & 78,62 & 32,13 & 286 & 4,88 & 3,43 & 560,2 & a) & & 6,0 \\
\hline 55 & A & 80,73 & 29,49 & 456 & 4,84 & 3,43 & 502,3 & a) & & 9,8 \\
\hline 57 & A & 80,98 & 17,43 & 507 & 2,40 & 1,11 & 219,5 & a) & & 8,0 \\
\hline 58 & A & 81,10 & 16,90 & 960 & 1,73 & 1,07 & 99,9 & a) & & \\
\hline 59 & A & 81,10 & 16,20 & 2044 & 2,14 & 1,70 & 41,9 & 44 & 0,9 & 4,6 \\
\hline 60 & B & 80,97 & 11,87 & 1950 & 1,19 & 1,26 & 9,0 & 33 & 0,3 & 3,8 \\
\hline 61 & E & 80,16 & 10,45 & 513 & 4,10 & 2,07 & 3365,8 & $18^{b)}$ & 189,1 & \\
\hline 62 & B & 80,91 & 9,89 & 1000 & 1,79 & 1,02 & 90,9 & 61 & 1,5 & \\
\hline 63 & B & 81,09 & 7,00 & 833 & 1,71 & 1,07 & 98,8 & 56 & 1,8 & \\
\hline 64 & B & 81,13 & 5,57 & 650 & 1,75 & 1,28 & 115,4 & 48 & 2,4 & 1,8 \\
\hline 65 & B & 81,23 & 2,19 & 1055 & 3,02 & 2,26 & 466,9 & 47 & 10,0 & 3,7 \\
\hline 67 & B & 81,29 & 0,34 & 2422 & 2,36 & 1,07 & 67,3 & 78 & 0,9 & 6,7 \\
\hline 68 & B & 81,42 & $-0,97$ & 2980 & 2,41 & $\underline{0,10}$ & 1,6 & 878 & 0,0 & \\
\hline 69 & B & 81,49 & $-5,41$ & 3580 & 2,25 & $\underline{0,52}$ & 0,3 & 152 & 0,0 & \\
\hline 70 & B & 81,52 & $-6,83$ & 2710 & 1,33 & $\overline{0,74}$ & 0,2 & 63 & 0,0 & 2,7 \\
\hline 73 & B & 81,58 & $-9,82$ & 1010 & 0,60 & $\underline{0,58}$ & 0,0 & 36 & 0,0 & \\
\hline 74 & B & 81,59 & $-10,02$ & 497 & 0,64 & 0,92 & 0,9 & 24 & 0,0 & 0,3 \\
\hline 79 & C & 82,44 & 1,44 & 3209 & 3,11 & $\underline{0,07}$ & 0,0 & 1567 & 0,0 & \\
\hline 82 & D & 82,38 & 3,70 & 2665 & 2,16 & $\overline{0,90}$ & 1,4 & 84 & 0,0 & \\
\hline 84 & D & 82,33 & 3,76 & 2150 & 2,54 & 1,02 & 138,6 & 87 & 1,6 & 2,0 \\
\hline 86 & D & 82,12 & 5,00 & 2000 & 3,41 & 2,64 & 437,6 & 45 & 9,7 & \\
\hline 87 & D & 82,04 & 5,31 & 1410 & 2,24 & 2,94 & 208,8 & 27 & 7,8 & \\
\hline 88 & D & 81,98 & 5,75 & 915 & 2,58 & 3,08 & 352,8 & 29 & 12,0 & \\
\hline 89 & D & 81,89 & 7,45 & 800 & 1,86 & 1,71 & 99,7 & 38 & 2,6 & 4,2 \\
\hline 91 & D & 81,68 & 10,41 & 1400 & 2,04 & $\underline{0,51}$ & 79,9 & 140 & 0,6 & 4,2 \\
\hline 93 & D & 81,27 & 13,00 & 2200 & 1,78 & $\overline{1,20}$ & 7,3 & 52 & 0,1 & 4,2 \\
\hline 94 & E & 80,59 & 11,90 & 1050 & 1,93 & 2,20 & 112,0 & a) & & \\
\hline 96 & E & 80,53 & 10,37 & 750 & 1,27 & 2,66 & 79,5 & a) & & \\
\hline 99 & $E$ & 80,17 & 10,40 & 514 & 3,16 & 3,30 & 1353,0 & $12^{b)}$ & 113,5 & 8,8 \\
\hline
\end{tabular}

\footnotetext{
a) export term not negligible

b) including export flux using eq. 2

${ }^{c}$ excluding values based on depletion $<0.6{\mathrm{dpm} \mathrm{cm}^{-2}}^{-2}$
} 
Table 2. List of parameters

h Height of bottom boundary layer (BNL) m

$\mathrm{C}_{\mathrm{pBNL}}$ : $\quad$ particulate activity of ${ }^{234} \mathrm{Th}$ in $\mathrm{BNL} \quad \mathrm{dpm} \mathrm{m}^{-3}$

$\mathrm{C}_{\mathrm{tBNL}}$ : total (dissolved+particulate) activity of ${ }^{234} \mathrm{Th}$ in BNL $\quad \mathrm{dpm} \mathrm{m}^{-3}$

$\mathrm{P}_{\mathrm{d}} \quad$ production rate of ${ }^{234} \mathrm{Th}$ from ${ }^{238} \mathrm{U} \quad \mathrm{dpm} \mathrm{m} \mathrm{m}^{-3} \mathrm{~d}^{-1}$

$\lambda$ : decay constant of ${ }^{234} \mathrm{Th} \quad \mathrm{d}^{-1}$

$\mathrm{w}_{\mathrm{S}} \quad$ particle settling rate $\mathrm{md}^{-1}$

$\mathrm{C}_{\mathrm{pc}} \quad$ particulate activity of ${ }^{234} \mathrm{Th}$ in clear water above BNL $\quad \mathrm{dpm} \mathrm{m}^{-3}$

$\mathrm{K}$ resuspension rate $\mathrm{d}^{-1}$

L Thickness of resuspension zone (surface sediment) m

$\mathrm{B}_{\mathrm{O}} \quad$ activity ( $\mathrm{dpm} \mathrm{m}^{-3}$ of particles) in particles in the resuspension zone

$\mathrm{D}: \quad$ Ingrowth from depletion in the BNL, $\mathrm{h}\left(\mathrm{P}_{\mathrm{d}}-\mathrm{C}_{\mathrm{tBNL}} \lambda\right) \quad \mathrm{dpm} \mathrm{m}-\mathrm{d}^{-1}$

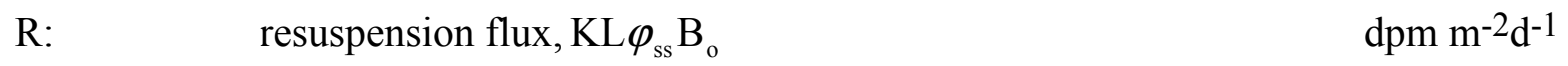

S: $\quad$ settling flux of ${ }^{234} \mathrm{Th},-\mathrm{w}_{\mathrm{s}} \mathrm{C}_{\mathrm{pc}} \quad \mathrm{dpm} \mathrm{m} \mathrm{m}^{-2} \mathrm{~d}^{-1}$

$\tau \quad$ residence time of suspended particles in the BNL d

$\mathrm{I}_{\mathrm{P}} \quad$ inventory of particulate ${ }^{234} \mathrm{Th}$ in the BNL $\mathrm{dpm} \mathrm{m} \mathrm{m}^{-2}$

$\mathrm{I}_{\mathrm{D}} \quad$ inventory of the depletion of ${ }^{234} \mathrm{Th}$ in the BNL $\mathrm{dpm} \mathrm{m}^{-2}$

$\mathrm{I}_{\text {Dsw }} \quad$ inventory of the depletion of ${ }^{234} \mathrm{Th}$ in the overlying water column $\mathrm{dpm} \mathrm{m}{ }^{-2}$

$\mathrm{F} \quad$ particle recycling rate $\mathrm{g} \mathrm{m}^{-2} \mathrm{~d}^{-1}$

$\mathrm{C}_{\mathrm{SPM}} \quad$ concentration of suspended particles in the BNL $\quad \mathrm{g} \mathrm{m}^{-3}$ 


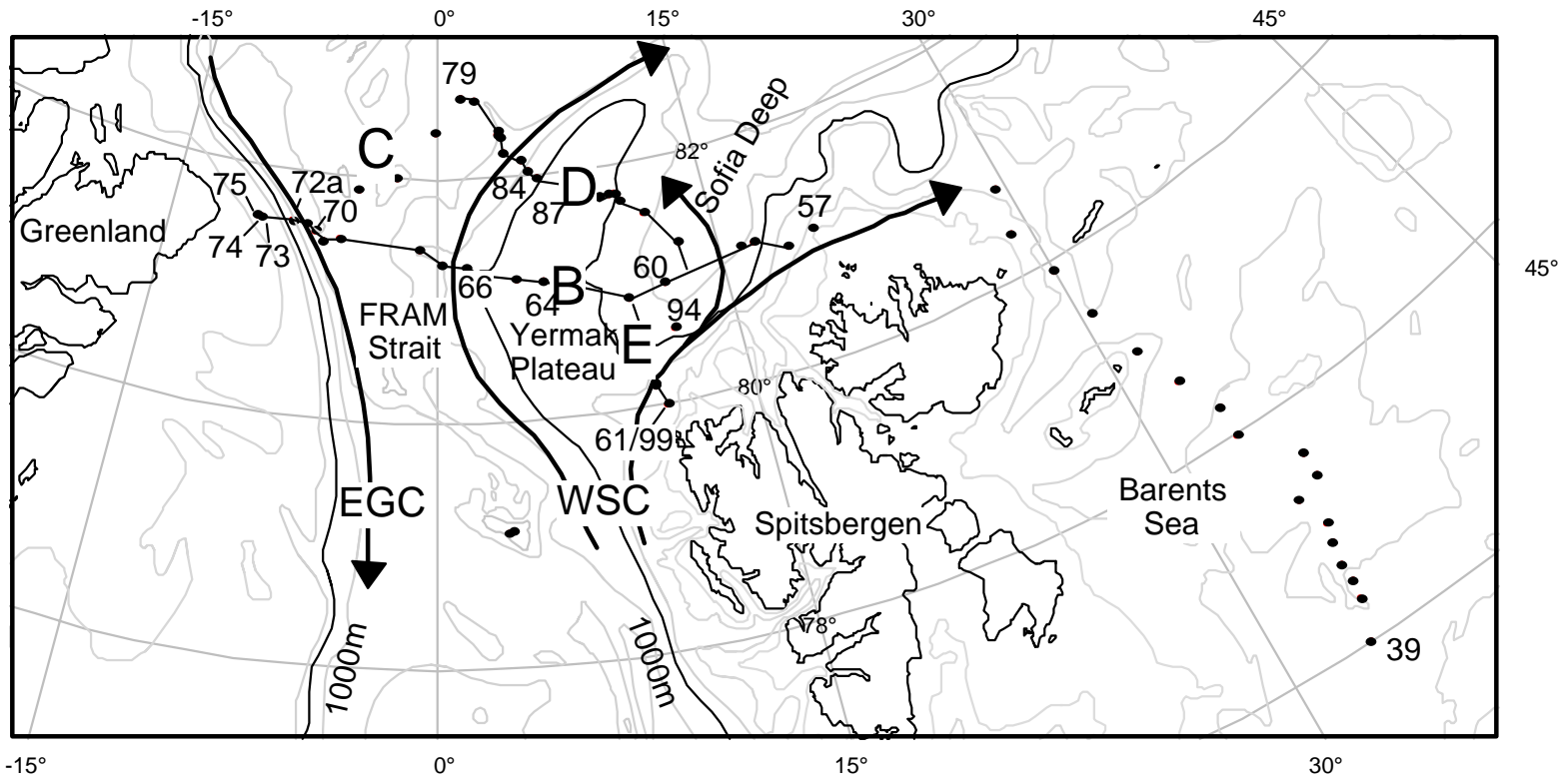

Figure 1 


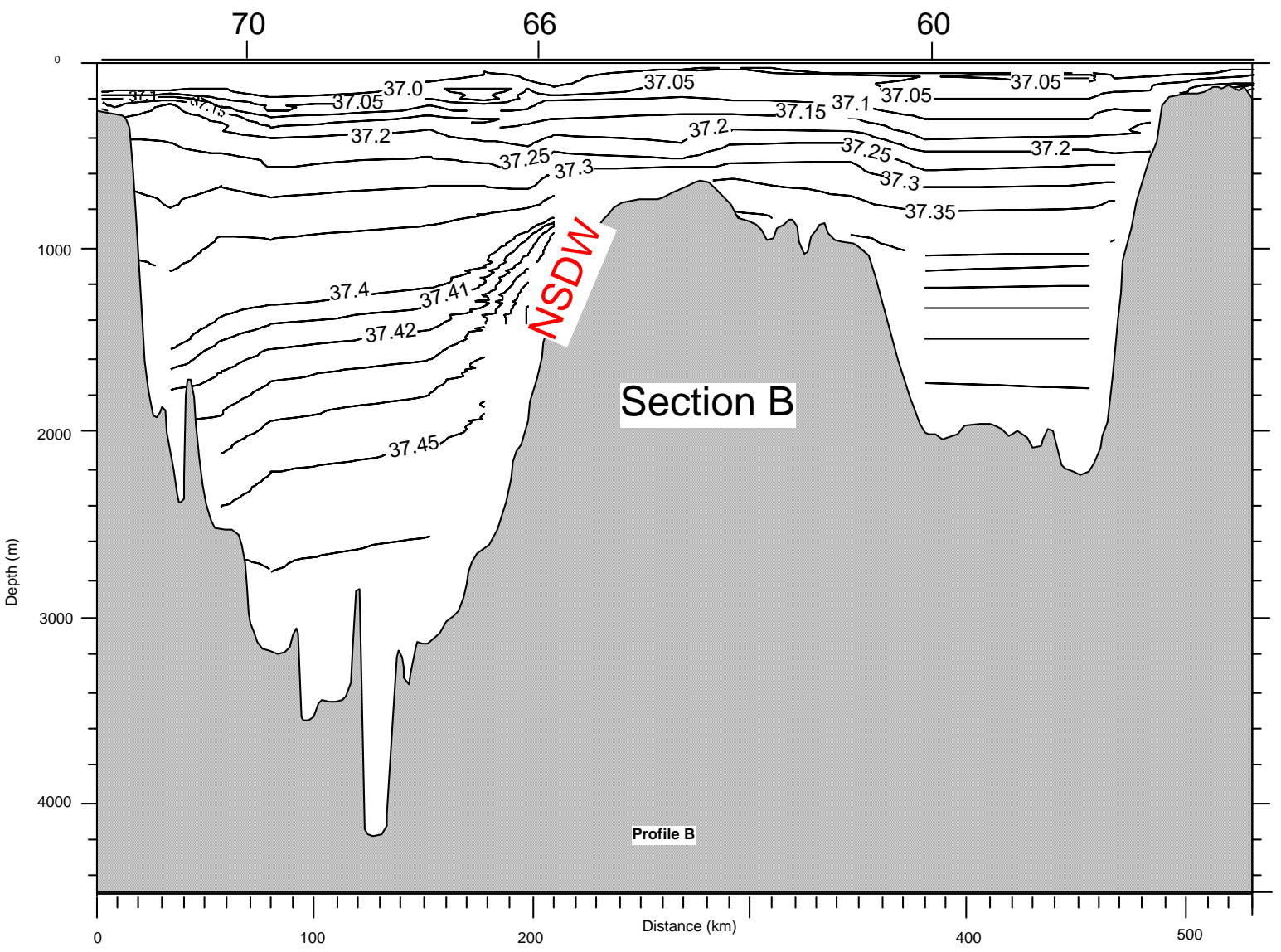

Figure 2 


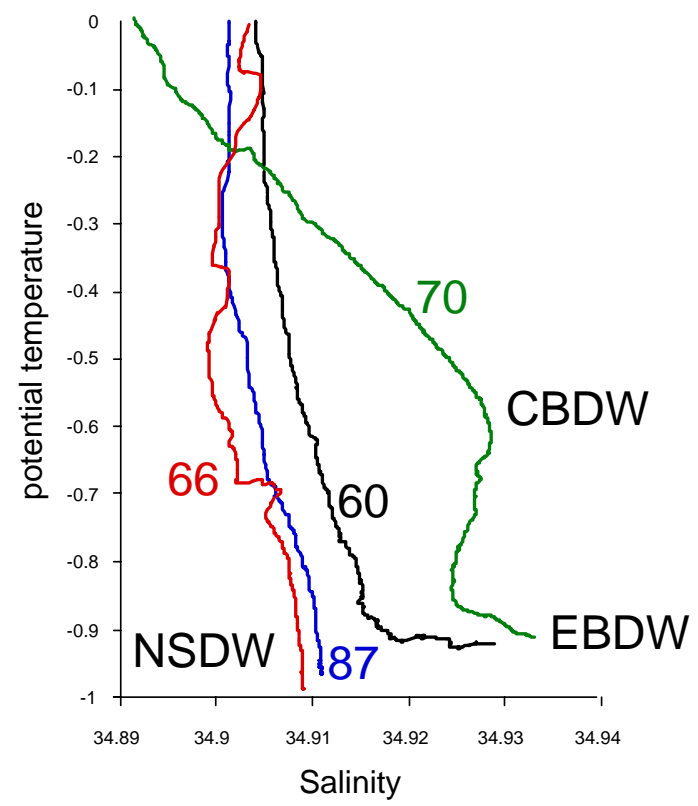

Figure 3 


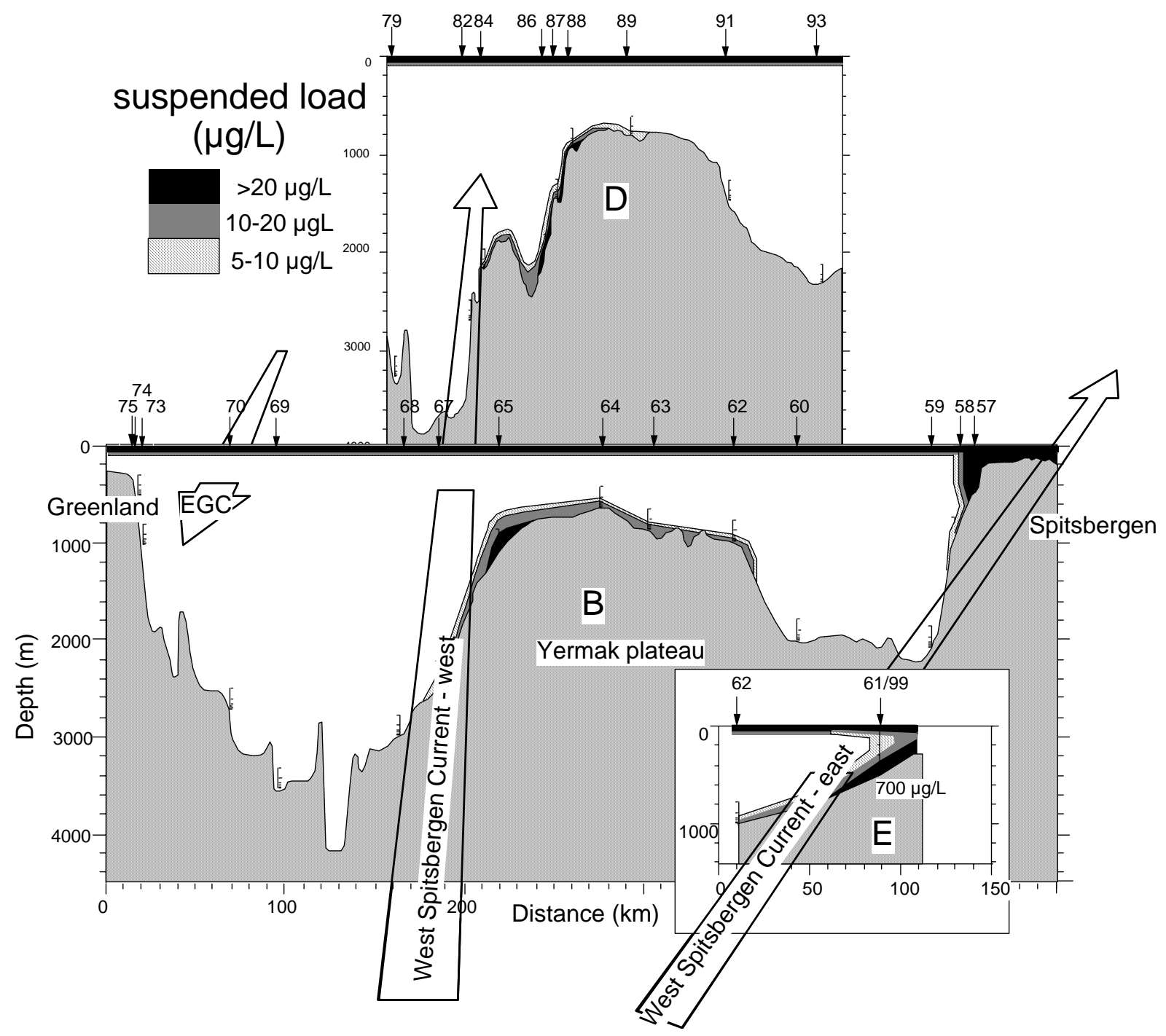

Figure 4 


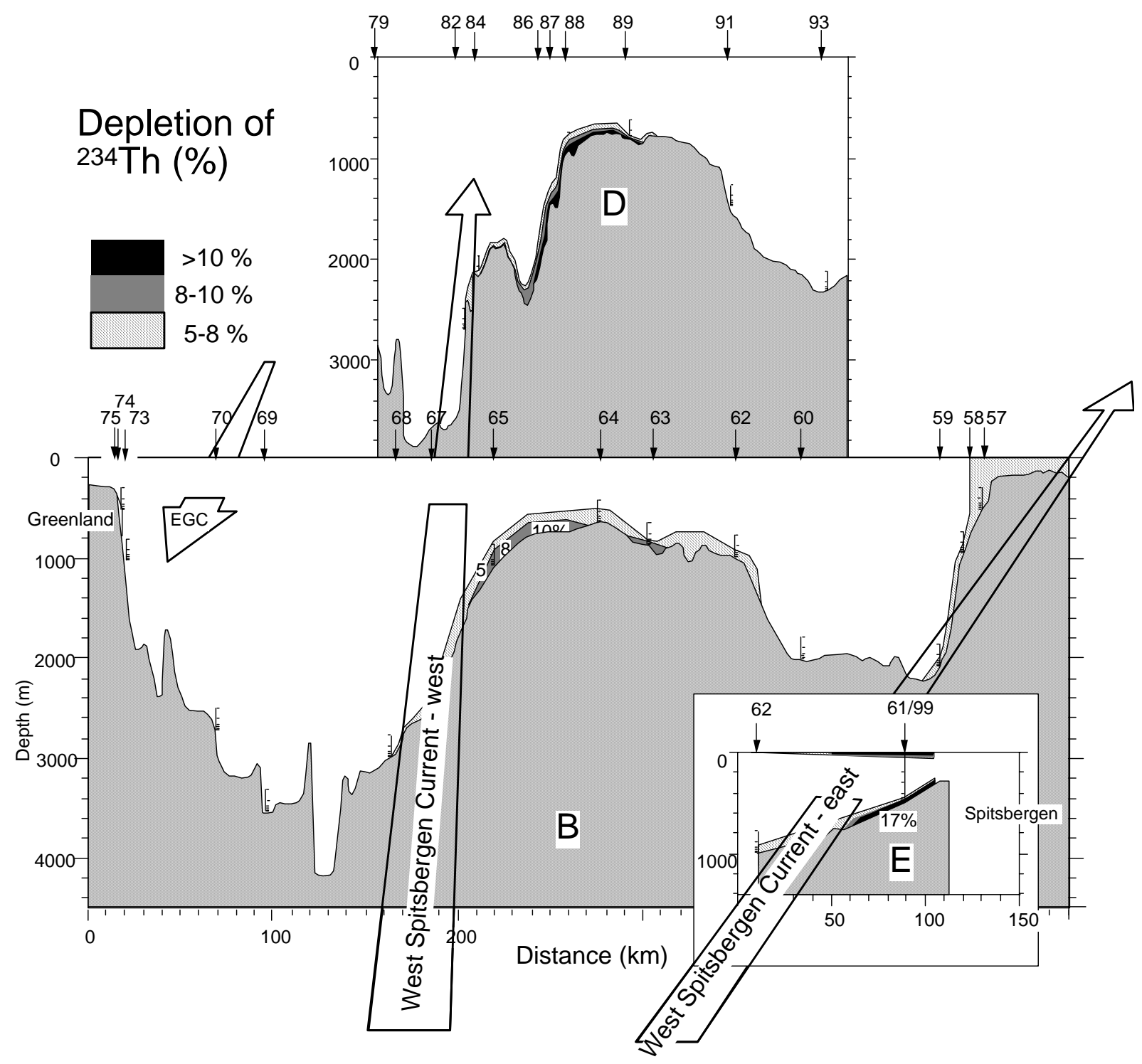

Figure 5 


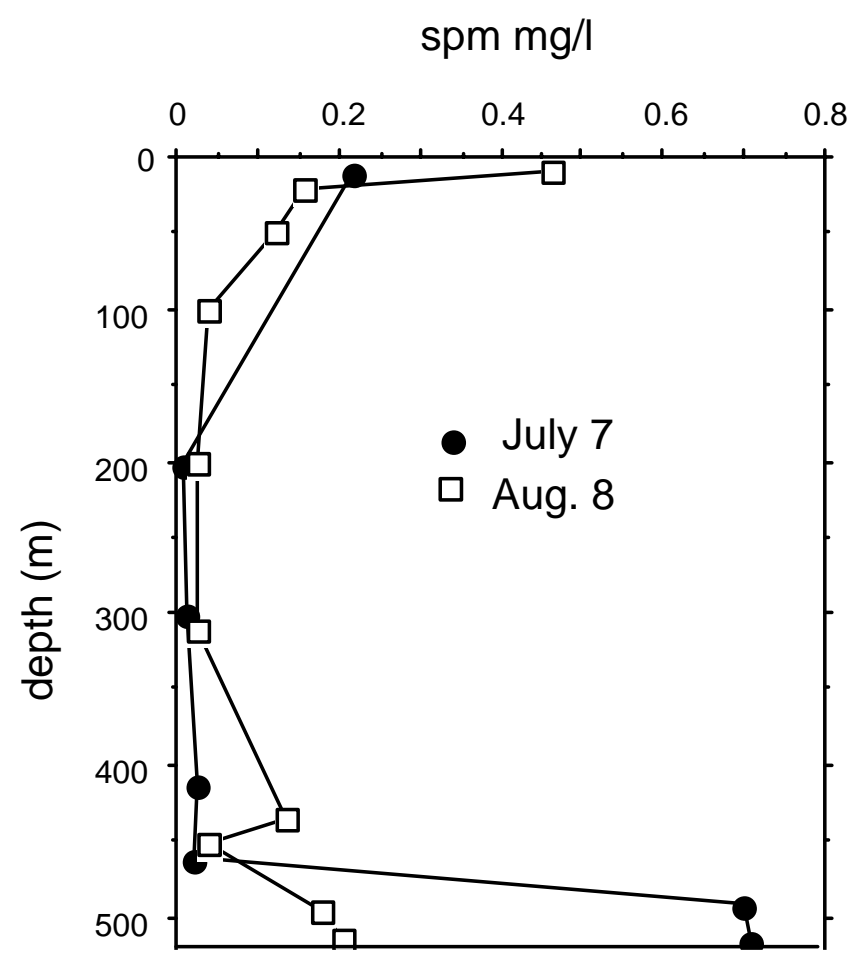

Figure 6 

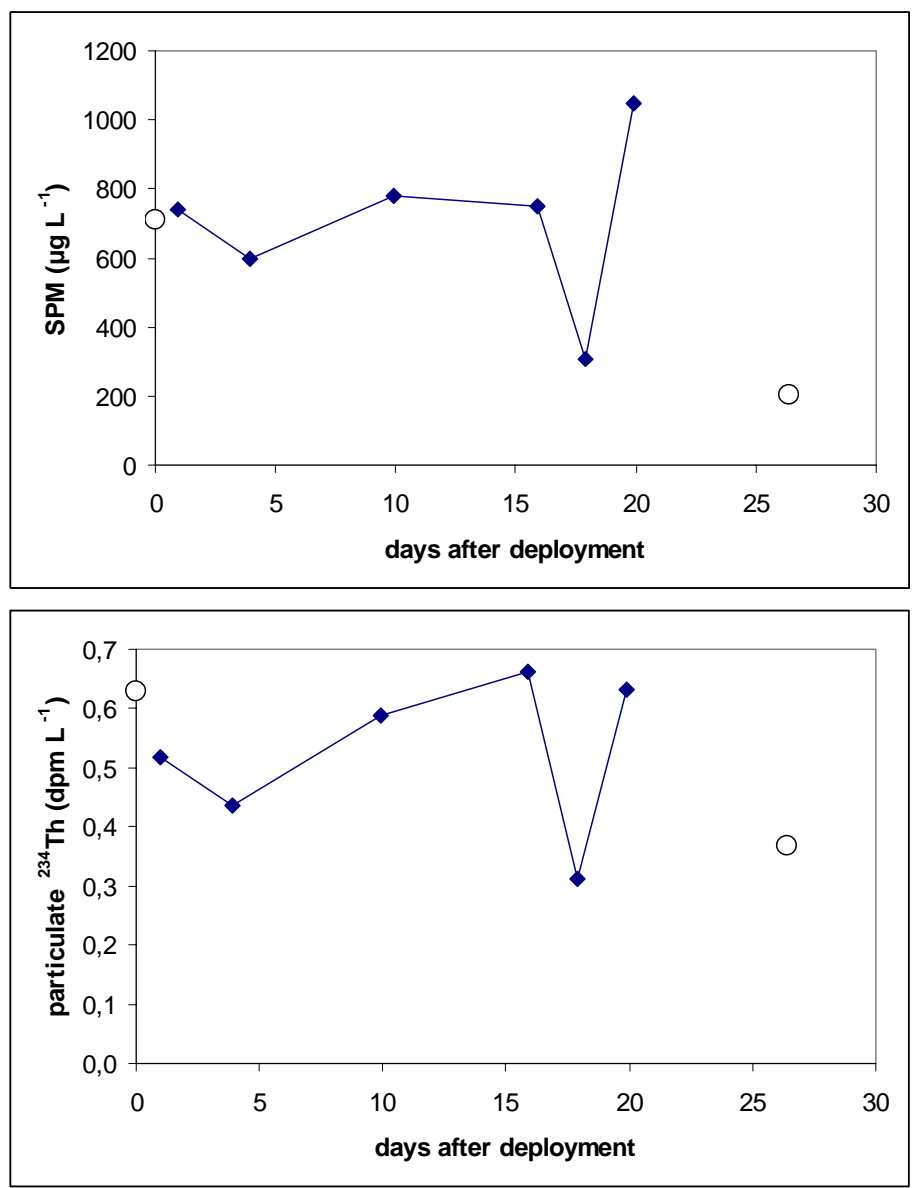

Figure 7 


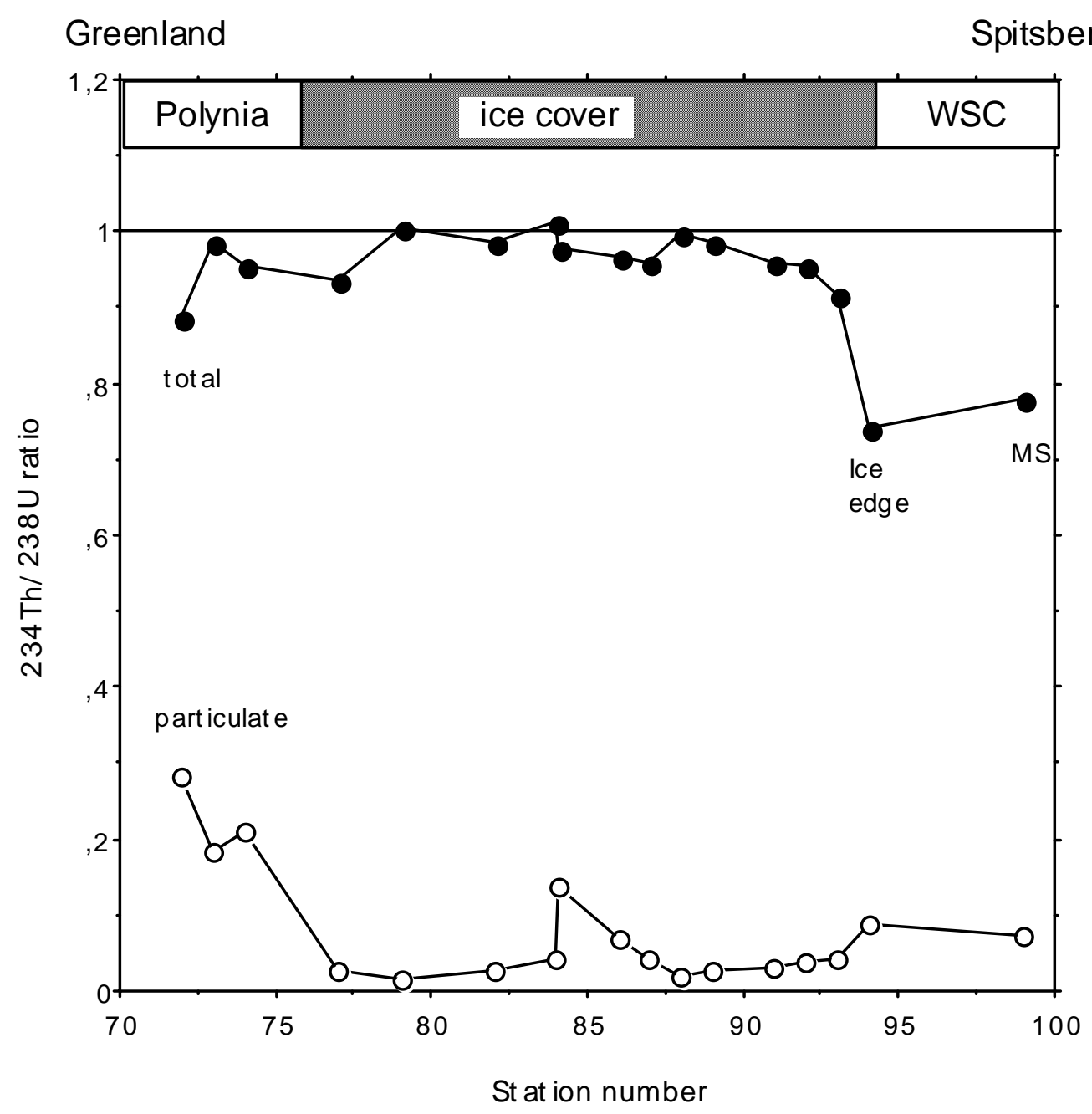

Figure 8 


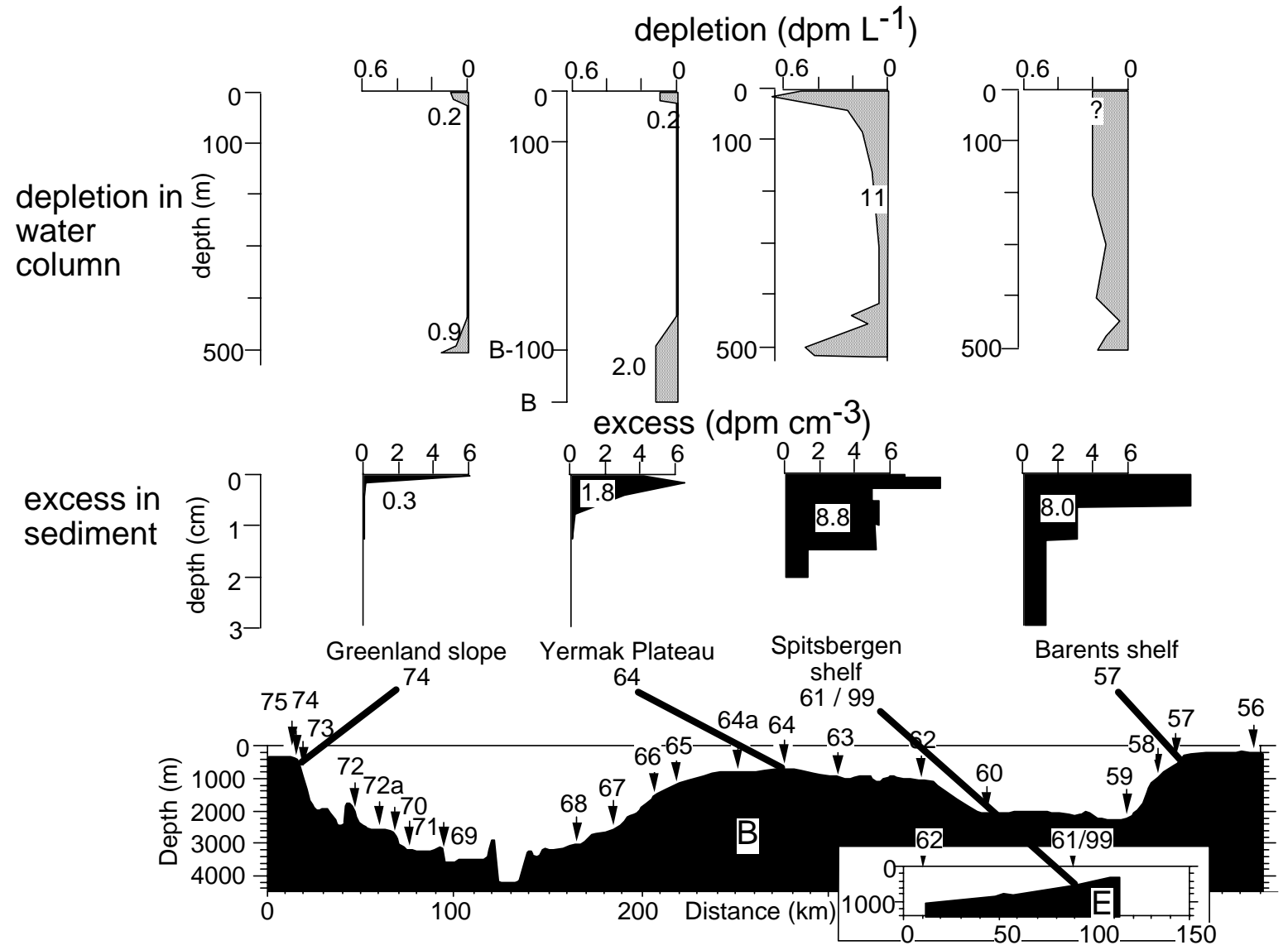

Figure 9 


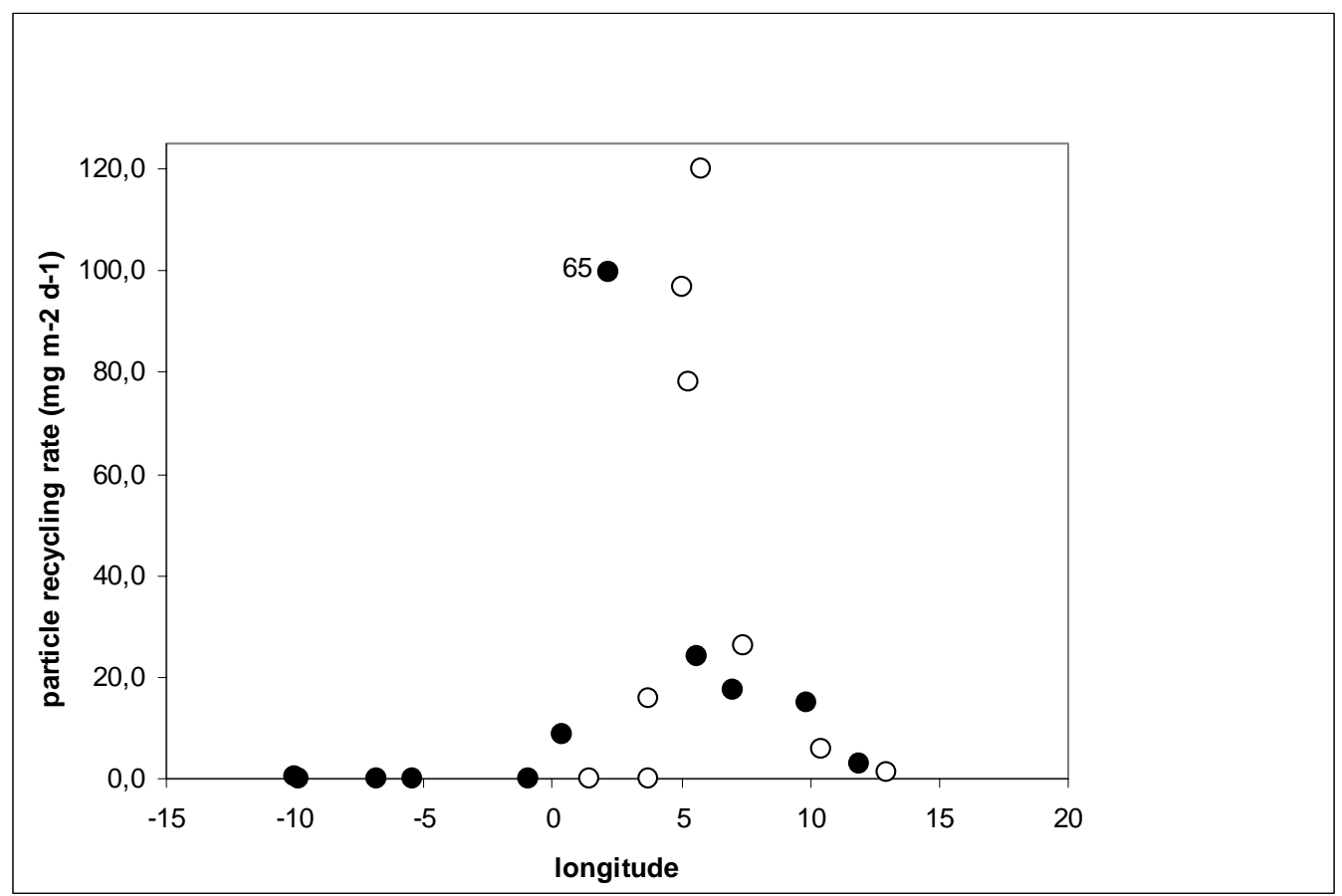

Figure 10 


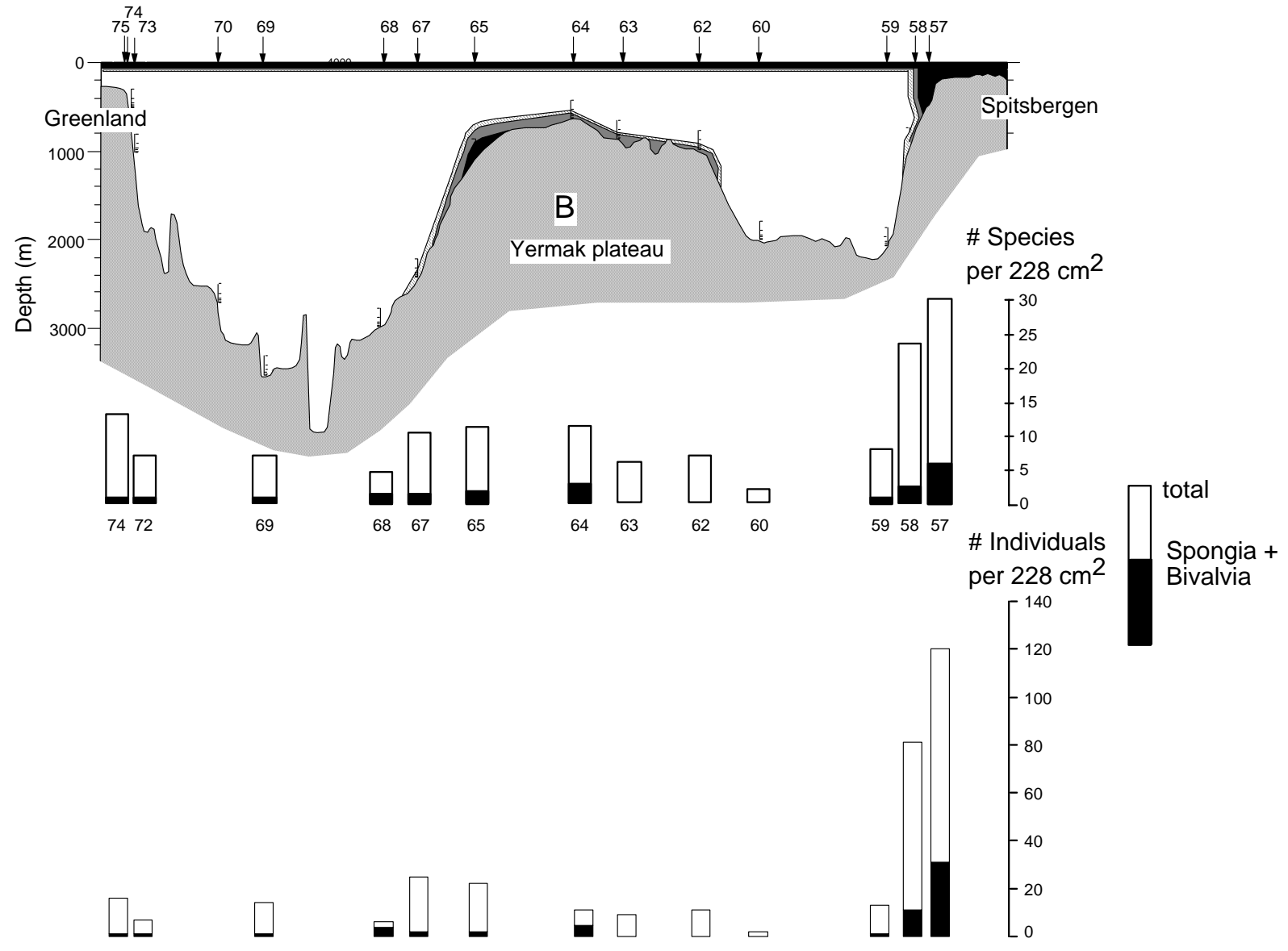

Figure 11 